\title{
IDENTIFIKASI MISKONSEPSI SISWA DENGAN CERTAINTY RESPONSE INDEX (CRI) MENGENAI KONSEP BILANGAN BULAT DI KELAS IVC SDN 7 KENDARI BARAT
}

\author{
Asmiar Bolo $^{1)}$, Izlan Sentryo ${ }^{1)}$, Nana Sumarna ${ }^{1)}$ \\ ${ }^{1)}$ Jurusan Pendidikan Guru Sekolah Dasar \\ FKIP Universitas Halu Oleo \\ Email: asmirabolo14092@gmail.com, izlan.sentryo@gmail.com, nanafkipunhalu@gmail.com
}

\begin{abstract}
Abstrak: Tujuan dalam penelitian ini selain untuk melihat siswa yang paham konsep, tidak paham konsep, dan miskonsepsi juga untuk melihat jenis-jenis kesalahan konsep (miskonsepsi) siswa dan klasifikasi miskonsepsinya di kelas $\mathrm{IV}_{\mathrm{C}}$ SDN 7 Kendari Barat pada konsep bilangan bulat dengan menggunakan tehnik CRI. Jenis penelitian ini adalah bersifat deskriptif dengan desain penelitian yang digunakan adalah studi kasus. Subyek dalam penelitian ini adalah siswa kelas IVc SDN 7 Kendari Barat. Teknik pengumpulan data yang digunakan dalam penelitian ini adalah teknik tes yang dilengkapi dengan teknik CRI untuk mengukur tingkat keyakinan siswa atas jawabannya dan teknik nontes yaitu dengan menggunakan lembar observasi dan lembar wawancara. Data dianalisis dengan menggunakan analisis deskriptif kuantitatif yang noneksperimen. Berdasarkan hasil analisis data yang diperoleh miskonsepsi siswa masih ditemukan pada konsep bilangan bulat yang dimana jenis kesalahannya salah dalam mengubah soal cerita kedalam kalimat matematika, salah dalam menentukan operasi hitung penjumlahan dan pengurangan dua bilangan bulat berlawanan tanda dan bertanda sama dan salah tanda positif dan negatif bilangan pada hasil akhir operasi hitung yang dilakukan untuk besar presentase miskonsepsinya yaitu untuk uji tes uraian pertama sebesar $31,25 \%$ pada butir soal nomor 1 , untuk uji tes uraian besar presentasenya $6,25 \%, 6,25 \%$, dan $9,38 \%$ pada butir soal 1,2 , dan 3, dan untuk uji tes uraian ketiga besar presentasenya $31,25 \%$ dan tergolong pada klasifikasi miskonsepsi berkategori rendah dan sedang.
\end{abstract}

Kata kunci : Identifikasi Miskonsepsi; Jenis Miskonsepsi; Klasifikasi Miskonsepsi; Bilangan Bulat

\section{IDENTIFICATION OF STUDENT'S MISCONCEPTION BY USING CERTAINTY RESPONSE INDEX (CRI) CONCERNING TO THE CONCEPT OF INTEGERS IN IVC CLASS SDN 7 WEST KENDARI}

Abstract: The way to find the causes is by using Certainty Response Index (CRI)technique, so this research intended to know the student that understand the concept, did not understand the concept, and misconception, also to know the kinds of the student's misconception and its classification in IVc Class, SDN 7 West Kendari at concept of integers by using CRI technique. This research is a kind of descriptive research and use "case study" as the research design. Technique of the data collection used in this research is test technique and also used CRI technique to measure the conviction level upon their answer and non-test technique, it is by using observation sheet and interview sheet. The data analyzed by using descriptive-qualitative analysis which is nonexperimentation. Based on the data analysis, misconception are still found in integers concept where the kind of mistake are fault in changing narrative question into mathematical sentence, fault in determining count-additional operation and fault in diminution of two integers amount with opposite mark and similar mark, and fault in positive and negative mark of amount in the final result of the counting operation that is done, the percentage of the misconception are: $31,25 \%$ in the first description test at question 1,2, and 3;6,25\%,6,25\% and 9,38\% in second description test at question 1,2, and 3; and 31,25\% in the third description test and included in the classification of misconception with low and medium category.

Keywords: Identification of misconception; kinds of misconception; classification of misconception; integers 


\section{Pendahuluan}

Menurut Rahayu (Sari, 2017:42), matematika merupakan salah satu mata pelajaran yang diberikan kepada semua peserta didik mulai dari sekolah dasar sampai dengan perguruan tinggi untuk membekali peserta didik dengan pemikiran yang logis, analitis, sistematis, kritis, kreatif, serta kemampuan pemahaman dalam hal bekerjasama. Kompetensi tersebut sangat diperlukan siswa agar memiliki kemampuan memperoleh, mengelolah, dan memanfaatkan informasi untuk bertahan hidup pada keadaan yang selalu berubah, tidak pasti, dan kompetitif. Dengan demikian peserta didik dapat memenuhi tujuan dari pendidikan matematika yang ingin dicapai. Adapun tujuan dari pendidikan matematika menurut Gravemeijer (Sari, 2017:42), yaitu sebagai prasyarat untuk pendidikan selanjutnya, sebagai kebutuhan praktis dalam kehidupan sehari-hari, berfikir matematika, dan sebagai pengembangan nilai-nilai kultur: pembelajaran yang demokrasi, keindahan matematika dan apresiasi peran matematika dalam masyarakat. Berdasarkan hal tersebut kini matematika dianggap sebagai ilmu yang sangat penting karena kemampuan matematika siswa dapat dimanfaatkan untuk menyelesaikan berbagai persoalan.

Melihat begitu pentingnya matematika, maka pembelajaran matematika itu selalu di ajarkan untuk setiap jenjang pendidikan. Menurut Nurlita dkk (2016:85), menyatakan bahwa penguasaan matematika yang baik tak terlepas dari pemahaman konsep matematika yang benar dan berkaitan antar konsep. Untuk itu pembelajaran matematika juga menekankan pada pemahaman konsep. Hal ini sesuai dengan pernyataan Zulkardi (Nurlita dkk, 2016:85), bahwa mata pelajaran matematika menekankan pada konsep artinya dalam mempelajari matematika pemahaman terhadap konsep yang merupakan hal utama untuk dapat menyelesaikan soal-soal dan mengaplikasikan pemahaman tersebut dalam dunia nyata. Namun disisi lain terdapat fakta ironis, sampai saat ini matematika masih menjadi masalah bagi sebagian siswa. Matematika sering diartikan oleh kebanyakan siswa sebagai ilmu yang berisi tentang perhitungan angka-angka yang rumit dan kumpulan aturan-aturan yang perlu untuk dipahami sehingga tak jarang siswa sulit dalam hal penguasaan konsep pembelajaran khususnya pada mata pelajaran matematika sebab siswa dihadapkan pada proses pengenalan rumus-rumus yang dianggap siswa sulit untuk di pelajari. Menurut Safitri dkk (2016 :401) pandangan tersebut muncul dari pengalaman siswa selama mempelajari matematika, sehingga ada sebagian siswa yang tidak menyukai matematika. Hal ini sejalan dengan menurut Suharsono (Asih, 2009:3), menyatakan bahwa sampai saat ini matematika masih saja dianggap sebagai bidang studi yang menakutkan oleh banyak siswa dan masih banyak siswa yang memperoleh hasil belajar yang kurang memuaskan. Menurut Ruseffendi (Ompusunggu, 2014:93), bahwa matematika bagi anak-anak pada umumnya merupakan mata pelajaran yang tidak disenangi, kalau bukan sebagian mata pelajaran yang dibenci. Sampai saat ini matematika masih dirasakan sebagai mok-mok oleh sebagian siswa, termaksud bagi siswa kelas $\mathrm{IV}_{\mathrm{C}}$ SDN 7 Kendari barat. Hal tersebut terbukti melalui hasil wawancara peneliti terhadap wali kelas yang bersangkutan yaitu" Sebagian besar siswa kurang antusias dalam belajar mata pelajaran matematika, Siswa kurang berani ketika ditunjuk untuk maju kedepan untuk menjawab soal-soal yang diberikan guru, IQ yang dimiliki siswa masih kurang sehingga guru hanya berfokus pada siswa yang pandai saja dimana sebagian siswa kebanyakan bercerita kepada teman saja sehingga kurang fokus pada apa yang di ajarkan, Mengenai materi dimana siswa paling banyak mendapatkan nilai rendah salah satunya terdapat pada materi konsep Bilangan bulat". ( sumber : wawancara dengan guru kelas $I V_{C}$ SDN 7 Kendari Barat, Senin 6 November 2017).

Sejalan dengan pernyataan diatas juga didukung berdasarkan hasil tes awal yang dilakukan peneliti terkait materi pokok bilangan bulat pada siswa yang telah menerima materi tersebut. Hasil menyatakan bahwa sebagian besar siswa masih kurang dalam pemahaman bilangan bulat terutama dalam menentukan garis bilangannya. Hal ini terbukti dari hasil tes awal "M.S dan Z R A" yang dimana menyatakan bahwa dalam menjawab soal nomor 1, "M.S" kurang paham dalam mengubah soal cerita kedalam kalimat matematika, tetapi mengerti dalam membuat garis bilangannya dan untuk soal nomor 2 siswa tersebut benar dalam menjawabnya. Sedangkan untuk hasil tes awal "Z R A" menyatakan bahwa dalam menjawab soal nomor 1, "Z R A" benar dalam menjawab tetapi untuk soal nomor 2 siswa tersebut kurang paham dalam menyelesaikan operasi penjumlahan dan pengurangan bilangan bulat terkait dalam mengoperasikan tanda operasi hitung jika bertemu dengan tanda bilangan negatif. Pernyataan diatas juga didukung melalui daftar nilai 
presentase ketuntasan siswa tahun ajaran 2016/2017 pada pembelajaran Matematika di kelas IVc SDN 7 Kendari Barat yang masih terlihat rendah seperti yang tersaji pada tabel 1.1 berikut :

Tabel 1. Daftar Presentase Ketuntasan Siswa Tahun Ajaran 2015/2016 pada pembelajaran matematika di kelas IV $_{\mathrm{C}}$ SDN 7 Kendari Barat

\begin{tabular}{lcc}
\hline Ketuntasan & Jumlah siswa & Presentase (\%) \\
\hline Tuntas & 6 & 25,0 \\
\hline Tidak tuntas & 18 & 75,75 \\
\hline Jumlah & 24 & 100 \\
\hline Sumber : Dokumentasi Guru Matematika & &
\end{tabular}

Berdasarkan Tabel 1 menunjukkan informasi bahwa nilai rata-rata siswa kelas $\mathrm{IV}_{\mathrm{C}}$ yang tuntas pada mata pelajaran matematika tahun ajaran 2015/2016 adalah dengan presentase 25\% sedangkan yang tidak tuntas sebanyak presentase $75 \%$ dengan Krikteria Ketuntasan Minimal (KKM) adalah 70 sedangkan untuk tahun ajaran 2017/2018 yaitu 75. Jadi apa bila dilihat dari ratarata nilai tersebut menyatakan bahwa hampir semua siswa kelas IVc hasil belajarnya tidak memenuhi pencapaian KKM yang telah ditentukan dari pihak sekolah. Rendahnya hasil belajar siswa ada kemungkinan permasalahan dalam pemahaman konsep matematika. Hal ini senada dengan informasi dari guru yang sekaligus walikelas IV SDN 7 Kendari Barat menyatakan bahwa pada beberapa materi sebagian siswa kesulitan dalam memahami konsep matematika terkhusus pada materi bilangan bulat. Bahkan dalam pembelajaran beliau juga tidak hanya menggunakan metode ceramah tetapi di variasikan dengan model-model pembelajaran diskusi dan tanya jawab. Hal ini masih saja membuat beberapa siswa ada yang masih mendapatkan nilai rendah.

Jika dilihat dalam pengertian pembelajaran matematika siswa dituntut untuk mempelajari konsep-konsep yang saling berkaitan. Bila salah satu konsep tidak dipelajari dengan baik maka akan berpengaruh pada pembelajaran konsep selanjutnya. Hal ini sejalan dengan menurut Hudojo (Sari, 2017:42), menyatakan bahwa matematika berhubungan dengan ide-ide/konsep-konsep abstrak yang tersusun secara hirarkis untuk mempelajarai suatu konsep yang berdasarkan pada konsep yang lain. Dengan demikian seseorang perlu memahami lebih dahulu konsep prasyarat tersebut, bila satu konsep tidak di pahami maka hal ini akan berdampak pada konsep-konsep selanjutnya. Kondisi demikian sangat memungkinkan timbulnya salah konsep (miskonsepsi). Pernyataan diatas sejalan dengan menurut Sumardoyo \& Gradini (Dzulfikar,.A,. 2017:42), yang menyatakan bahwa miskonsepsi yang terjadi pada jenjang pendidikan khususnya pada pembelajaran matematika masih banyak ditemuka pada siswa sekolah dasar diantaranya terkait konsep bilangan dan geometri. Sementara Miskonsepsi itu sendiri jika diartikan menurut Gradini (2016:53), menyatakan bahwa miskonsepsi menyangkut pada pemahaman atau pemikiran yang tidak berlandaskan pada informasi yang tepat. Miskonsepsi dalam matematika dapat menjadi masalah serius jika tidak segera diperbaiki sebab kesalahan satu konsep saja dapat menentukan pada kesalahan yang terus menerus. Terkait permasalahan yang terdapat pada obsevasi awal yang dilakukan peneliti mengenai permasalahan yang ada pada siswa kelas IVC SDN 7 Kendari Barat yaitu terdapat pada materi Bilangan Bulat. Hal tersebut terbukti melalui pemaparan sebelumnya yang telah di jelaskan. Dimana disini peneliti ingin melihat apakah siswa kelas IVC SDN 7 Kendari Barat miskonsepsi yang dialami oleh siswa.

Oleh karena itu sebagai salah satu alternatif dalam mengidentifikasi miskonsepsi adalah dengan tehnik Certainty Response Index (CRI) yang dikembangkan oleh Saleem Hasan. Menurut Hasan (Tuyubi, 2005:5) menyatakan bahwa tehnik Certainty Response Index (CRI) merupakan ukuran tingkat keyakinan/kepastian responden dalam menjawab setiap pertanyaan (soal) yang diberikan. CRI biasanya didasarkan pada suatu skala dan diberikan bersamaan dengan setiap jawaban suatu soal. Tingkat kepastian tersebut digambarkan dalam skala CRI yang diberikan tersebut. Pernyataan tersebut di dukung oleh hasil penelitian yang telah di lakukan oleh Tuyubi dari penelitiannya telah dilakukan bahwa metode Certainty Response Index (CRI) dapat mengidentifikasi miskonsepsi yang dimiliki siswa. Untuk itu peneliti mencoba mengetahui miskonsepsi siswa dengan menggunakan teknik Certainty Of Response Index (CRI) maka diadakan penelitian mengenai "Identifikasi Miskonsepsi Siswa dengan Certainty Response Index (CRI) mengenai Konsep Bilangan Bulat di kelas IV ${ }_{C}$ SDN 7 Kendari Barat”. 


\section{Metode Penelitian}

Jenis penelitian ini adalah bersifat deskriptif dengan desain penelitian yang digunakan adalah studi kasus. Subyek dalam penelitian ini adalah siswa kelas IVc SDN 7 Kendari Barat yang dimana untuk memilih sampel dalam penelitian ini yaitu setelah melakukan tes yang dilengkapi dengan tehnik CRI sebanyak tiga kali untuk menetukan jumlah sampel yang miskonsepsi. Teknik pengumpulan data yang digunakan dalam penelitian ini adalah teknik tes yang dilengkapi dengan teknik CRI untuk mengukur tingkat keyakinan siswa atas jawabannya dan teknik nontes yaitu dengan menggunakan lembar observasi dan lembar wawancara.

Instrumen yang digunakan yaitu Peneliti, yang menjadi instrumen utama (pengumpulan data) dan instrumen pelengkap yaitu wawancara, observasi dan tes yang dilengkapi dengan tehnik Certainty Response Index berikut tabelnya :

\begin{tabular}{cl}
\hline CRI & Krikteria \\
\hline 0 & Menebak (Totally guessed answer) \\
\hline 1 & Agak menebak (Almost guess) \\
\hline 2 & Tidak yakin (Not sure) \\
\hline 3 & Agak yakin (sure) \\
\hline 4 & Yakin (Almost Certain) \\
\hline 5 & Sangat yakin (Certain) \\
\hline (Hasan, 1999)
\end{tabular}

Tehnik mengelolahan data dalam penelitian ini adalah menggunakan rumus statistik sederhana sebagai berikut: $\quad \mathrm{P}=\frac{F}{N} \times 100 \%$. Atau persentase $=\frac{T K / T T K / M / T M}{N} \times 100 \%$.

Keterangan :

$\mathrm{F}=$ frekuaensi yang sedang dicari

\begin{tabular}{|c|c|c|}
\hline $\begin{array}{l}\text { Krikteria } \\
\text { jawaban }\end{array}$ & CRI rendah $(\mathrm{CRI}<25)$ & CRI tinggi (CRI>25) \\
\hline Jawaban benar & $\begin{array}{c}\text { Jawaban benar tapi CRI } \\
\text { rendah } \\
\text { Tidak tahu konsep }\end{array}$ & $\begin{array}{c}\text { Jawaban benar dan CRI tinggi } \\
\text { Menguasai konsep dengan } \\
\text { baik }\end{array}$ \\
\hline Jawaban salah & $\begin{array}{c}\text { Jawaban salah tapi CRI } \\
\text { rendah } \\
\text { Tidak tahu konsep }\end{array}$ & $\begin{array}{c}\text { Jawaban salah dan CRI tinggi } \\
\text { Terjadi miskonsepsi }\end{array}$ \\
\hline
\end{tabular}

\section{Hasil Penelitian}

Dari hasil penelitian yang telah dilakukan, dimana masih ditemukan siswa yang mengalami miskonsepsi pada materi bilangan bulat dengan menggunakan tehnik certainty respose index (CRI), berikut deskripsi hasil observasi yang dilakukan : Untuk indikator kedua menjawab pertanyaan hanya sekitar 3 siswa yang berani menjawab pertanyaan guru didepan kelas dengan baik, sedangkan 29 orang siswa kurang. Untuk indikator ketiga keberanian bertanya dimana tidak ada siswa yang berani untuk bertanya ketika guru menanyakan hal-hal yang belum dimengerti. Untuk indikator keempat aktif dalam bekerja sama hanya sekitar 15 siswa yang dalam penilaian baik ketika bekerja sama, sedangkan 17 siswa kurang dalam hal ini hanya menunggu jawaban dari teman sebangkunya. 
Hasil deskripsi materi yang tergolong miskonsepsi pada materi bilangan bulat yaitu :

Tabel 3. Hasil Data Indikator Materi Bilangan Bulat Yang Mengalami Miskonsepsi Untuk Soal Tes Pertama (1)

\begin{tabular}{|c|c|c|c|}
\hline \multirow[t]{2}{*}{ No } & \multirow{2}{*}{$\begin{array}{l}\text { Indikator materi bilangan } \\
\text { bulat }\end{array}$} & Miskonsepsi & \multirow[t]{2}{*}{ Nomor soa } \\
\hline & & Tidak & \\
\hline 1 . & Penjumlahan bilangan bulat & Tidak & - \\
\hline 2. & Pengurangan bilangan bulat & Tidak & - \\
\hline 3. & $\begin{array}{l}\text { Operasi hitung campuran } \\
\text { bilangan bulat }\end{array}$ & Ya & 3 \\
\hline
\end{tabular}

Tabel 4. Hasil Data Indikator Materi Bilangan Bulat Yang Mengalami Miskonsepsi Untuk Soal Tes kedua (2)

\begin{tabular}{|c|c|c|c|}
\hline \multirow[t]{2}{*}{ No } & \multirow{2}{*}{$\begin{array}{l}\text { Indikator materi bilangan } \\
\text { bulat }\end{array}$} & Miskonsepsi & \multirow[t]{2}{*}{ Nomor soal } \\
\hline & & $\begin{array}{ll}\text { Ya } & \text { Tidak }\end{array}$ & \\
\hline 1. & Penjumlahan bilangan bulat & $\mathrm{Ya}$ & 1 \\
\hline 2. & Pengurangan bilangan bulat & $\mathrm{Ya}$ & 2 \\
\hline 3. & $\begin{array}{l}\text { Operasi hitung campuran } \\
\text { bilangan bulat. }\end{array}$ & Ya & 3 \\
\hline
\end{tabular}

Tabel 5. Hasil Data Indikator Materi Bilangan Bulat Yang Mengalami Miskonsepsi Untuk Soal Tes ketiga (3)

\begin{tabular}{|c|c|c|c|}
\hline \multirow[t]{2}{*}{ No. } & \multirow[t]{2}{*}{ Indikator materi bilangan bulat } & Miskonsepsi & \multirow[t]{2}{*}{ Nomor soal } \\
\hline & & Tidak & \\
\hline 1. & Penjumlahan bilangan bulat & $\mathrm{Ya}$ & 1 \\
\hline 2. & Pengurangan bilangan bulat & Tidak & - \\
\hline 3. & $\begin{array}{l}\text { Operasi hitung campuran } \\
\text { bilangan bulat. }\end{array}$ & Tidak & - \\
\hline
\end{tabular}

\section{Pembahasan}

Berdasarkan hasil tes dengan menggunakan tehnik CRI berikut ditemukan jenis-jenis kesalahan siswa berikut tertera dalam bentuk tabel :

Tabel 6. Deskripsi jenis-jenis kesalahan konsep siswa (miskonsepsi) pada materi bilangan bulat.

\begin{tabular}{|c|c|c|c|c|}
\hline $\begin{array}{l}\text { Soal } \\
\text { Tes }\end{array}$ & $\begin{array}{l}\text { No } \\
\text { soal. }\end{array}$ & $\begin{array}{c}\text { Bentuk jawaban } \\
\text { siswa }\end{array}$ & Identifikasi kesalahan & $\begin{array}{c}\text { Jumlah } \\
\text { siswa }\end{array}$ \\
\hline $\begin{array}{c}\text { Tes } \\
1\end{array}$ & 3 & $\begin{array}{c}10 \mathrm{~m}+12 \mathrm{~m}+10 \mathrm{~m}=32 \\
\mathrm{~m}\end{array}$ & $\begin{array}{l}\text { Siswa salah dalam mengubah soal } \\
\text { cerita dalam bentuk kalimat } \\
\text { matematika, yang dimana siswa } \\
\text { menuliskan } \\
10 \mathrm{~m}+12 \mathrm{~m}+10 \mathrm{~m}=\ldots \text { ? seharusnya } \\
-10+(-12)+10=\ldots \text { ? sehingga hasil } \\
\text { akhirnya salah. }\end{array}$ & 10 \\
\hline $\begin{array}{c}\text { Tes } \\
2\end{array}$ & 1 & $-4^{0} \mathrm{c}+6^{0} \mathrm{c}=10^{0} \mathrm{c}$ & $\begin{array}{l}\text { Siswa salah melakukan operasi } \\
\text { hitung sehingga salah dalam } \\
\text { menentukan hasil operasi hitungnya } \\
\text { yang dimana }-4^{0} \mathrm{c}+6^{0} \mathrm{c}=. . ? \text {, } \\
\text { seharusnya hasilnya }-2^{0} \mathrm{c} .\end{array}$ & 2 \\
\hline
\end{tabular}




\begin{tabular}{|c|c|c|c|c|}
\hline $\begin{array}{c}\text { Soal } \\
\text { Tes }\end{array}$ & $\begin{array}{l}\text { No } \\
\text { soal. }\end{array}$ & $\begin{array}{c}\text { Bentuk jawaban } \\
\text { siswa }\end{array}$ & Identifikasi kesalahan & $\begin{array}{c}\text { Jumlah } \\
\text { siswa }\end{array}$ \\
\hline & 2 & $\begin{array}{c}\text { Dua bentuk jawaban } \\
\text { yaitu } \\
-6 m-4 m=10 \\
-6 m-4 m=-2\end{array}$ & $\begin{array}{l}\text { Siswa salah dalam menentukan tanda } \\
\text { bilangan positif dan negatifnya } \\
\text { sehingga salah pada hasil akhir } \\
\text { operasi hitungnya yang dimana }-6 \mathrm{~m} \\
-4 \mathrm{~m}=. . \text { ? seharusnya hasil }\end{array}$ & 2 \\
\hline & 3 & $\begin{array}{c}16+4-6 \\
=14 \mathrm{~m}\end{array}$ & $\begin{array}{l}\text { akhir operasi hitungnya }-10 \text { dan juga } \\
\text { Siswa salah dalam mengubah soal } \\
\text { cerita kedalam kalimat matematika } \\
\text { yang dimana siswa menuliskan } \\
16+4-6=. . ? \text { seharusnya } \\
-16+4-6=. . ?\end{array}$ & 3 \\
\hline $\begin{array}{c}\text { Tes } \\
3\end{array}$ & 2 & $\begin{array}{c}\text { Dua bentuk jawaban } \\
\text { yaitu } \\
-6 m-4 m=10 \\
-6 m-4 m=-2\end{array}$ & $\begin{array}{l}\text { Siswa salah dalam menentukan tanda } \\
\text { bilangan positif dan negatifnya } \\
\text { sehingga salah pada hasil akhir } \\
\text { operasi hitungnya yang dimana }-6 \mathrm{~m} \\
-4 \mathrm{~m}=. . \text { ? seharusnya hasil }\end{array}$ & 2 \\
\hline & 3 & $\begin{array}{c}16+4-6 \\
=14 \mathrm{~m}\end{array}$ & $\begin{array}{l}\text { akhir operasi hitungnya }-10 \text { dan juga } \\
\text { Siswa salah dalam mengubah soal } \\
\text { cerita kedalam kalimat matematika } \\
\text { yang dimana siswa menuliskan } \\
16+4-6=. . ? \text { seharusnya } \\
-16+4-6=. . ?\end{array}$ & 3 \\
\hline & 1 & $10+20=30 \mathrm{~m}$ & $\begin{array}{l}\text { Siswa salah dalam mengubah kalimat } \\
\text { soal cerita kedalam kalimat } \\
\text { matematika yang dimana siswa } \\
\text { menuliskan } \\
10+20=. . ? \text { seharusnya } \\
-10+(-20)=. . ?\end{array}$ & 10 \\
\hline
\end{tabular}

Berdasarkan hasil tes uraian menggunakan tehnik Certainty response index (CRI) untuk uji tes uraian pertama (1), kedua (2), dan ketiga (3) menunjukkan bahwa masih banyak siswa yang mengalami miskonsepsi. Berikut tabulasi mengenai persentase data siswa pahan konsep, miskonsepsi, tidak paham konsep, dan tidak menjawab yang dimana dikategorikan pada klasifikasi miskonsepsi yang dapat dilihat pada pengkategorian atau klasifikasi miskonsepsi tersebut.

\begin{tabular}{cc}
\hline Persentase & Kategori \\
\hline $0-30 \%$ & Rendah \\
\hline $31 \%-60 \%$ & Sedang \\
\hline $61 \%-100 \%$ & Tinggi \\
\hline
\end{tabular}

Sumber: (Rizky, U., D., \& dkk : 2017)

Berikut kalsifikasi miskonsepsi siswa Berdasarkan hasil tes uraian menggunakan tehnik Certainty response index (CRI) untuk uji tes uraian pertama (1), kedua (2), dan ketiga (3) dengan indikator penjumlahan, pengurangan, dan hitung campuran bilangan bulat yang digambarkan dalam bentuk diagram batang mengenai persentase miskonsepsinya. 
Jurnal Ilmiah Pembelajaran Sekolah Dasar

Volume 2 Nomor 1 - Februari 2020, e-ISSN 2656-0402

Available online at:http://ojs.uho.ac.id/index.php/jipsd

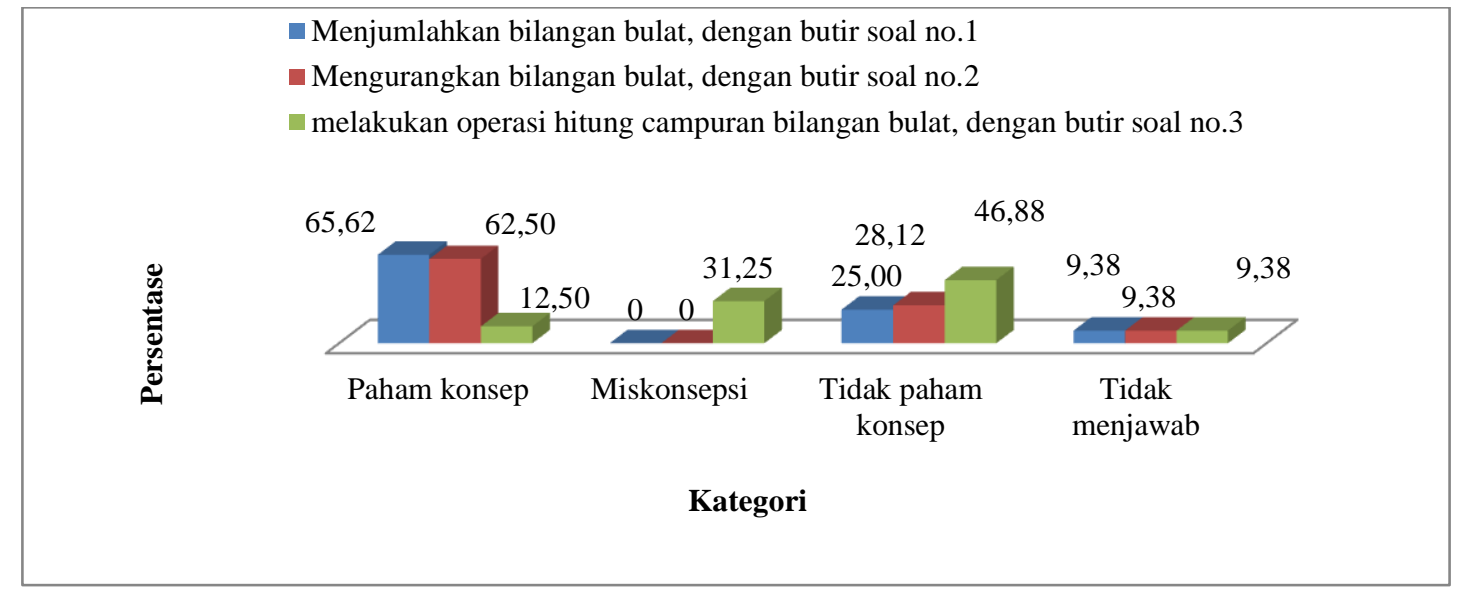

Gambar 1. Diagram Batang Untuk Soal Tes Pertama

Sehingga dapat di simpulkan bahwa untuk tes pertama butir soal nomor 3 tergolong atau di kategorikan miskonsepsi sedang sebab persentase nya terdapat pada kategori 31\%-60\%.

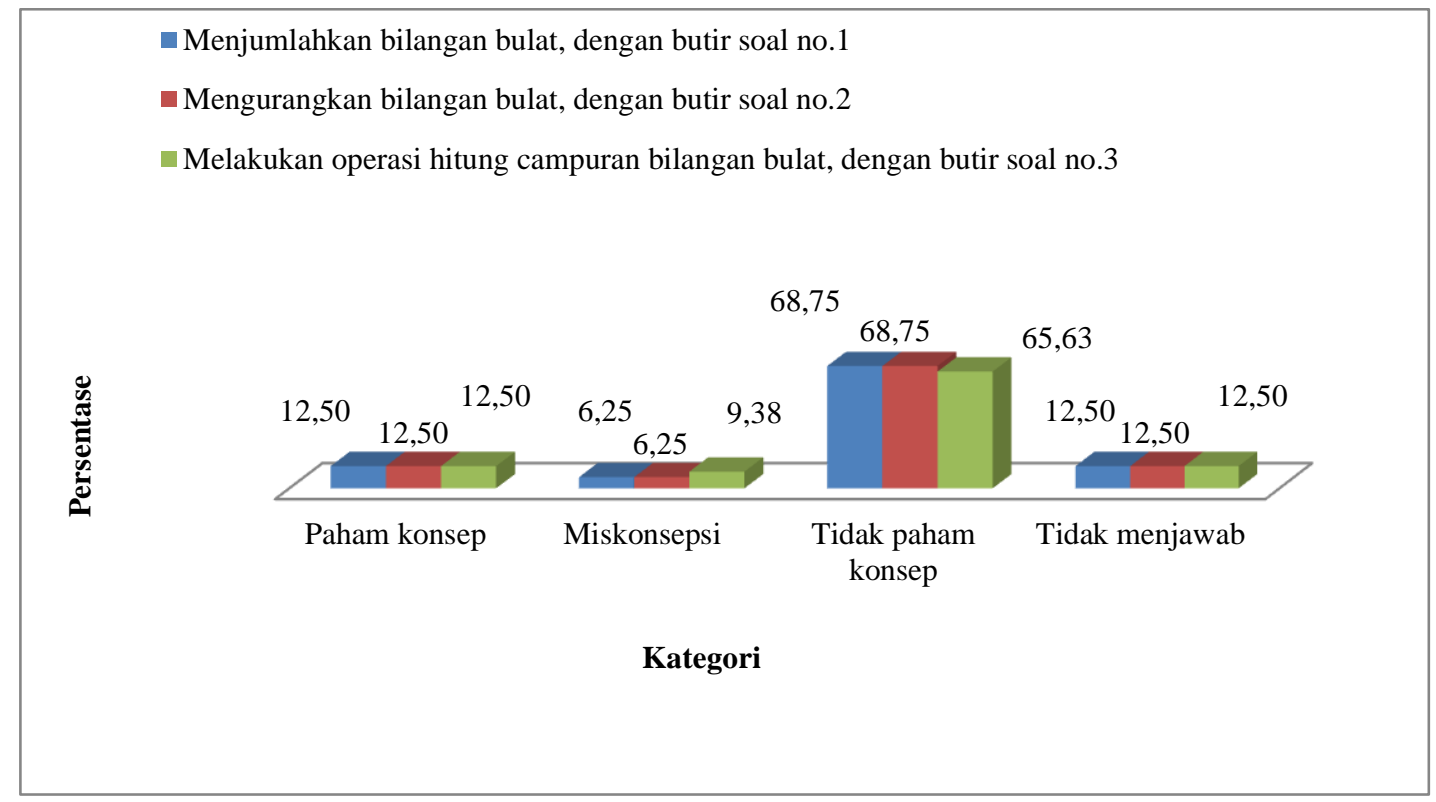

Gambar 2. Diagram batang untuk soal tes kedua

Sehingga dapat di simpulkan bahwa untuk tes ketiga butir soal nomor 1,2,dan 3 tergolong atau di kategorikan miskonsepsi rendah sebab presentase nya terdapat pada kategori $0 \%$ $30 \%$. 


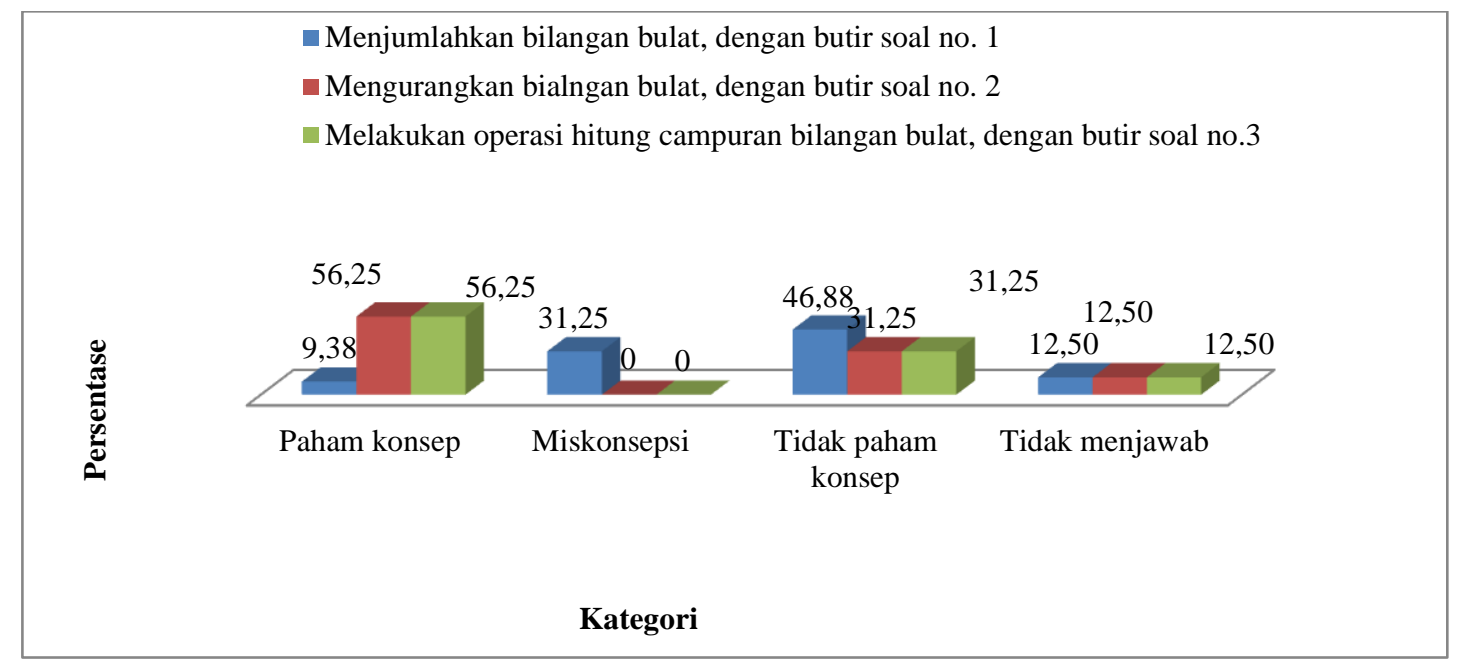

Gambar 3. Diagram batang untuk soal tes ketiga

Sehingga dapat di simpulkan bahwa untuk tes ketiga butir soal nomor 3 tergolong atau di kategorikan miskonsepsi sedang sebab presentase nya terdapat pada kategori 31\%-60\%.

Berdasarkan deskripsi hasil wawancara tersebut dapat disimpulkan bahwa siswa tidak utuh dalam memahami konsep bilangan bulat khususnya pada operasi hitung campuran bilangan bulat terutama dalam hal memahami soal cerita ketika diubah dalam bentuk kalimat matematikanya yang dimana terlihat sekali kekeliruan siswa untuk mengubah soal cerita tersebut sehingga terjadi kesalahan pada siswa saat menjawab soal, kesalahan ini juga nampak pada uji tes kedua dan ketiga. Selain itu siswa juga terlihat siswa hanya memahami konsep yang berusaha menghubungkan dengan pola pikirnya saja tanpa mendalaminya kembali sehingga siswa keliru dalam menjawab soal tersebut dan juga terlihat jelas bahwa siswa salah dalam mengoperasikan tanda operasi hitung jika bertemu dengan tanda bilangan yang dimana dalam menentukan operasi hitung penjumlahan dan pengurangan dua bilangan bulat berlawanan tanda dan bertanda sama. Dan juga terlihat ada beberapa subyek yang mengalami kesulitan dalam hal pembuatan garis bilangan yang sering kali keliru.

\section{Simpulan}

Berdasarkan hasil analisis data yang diperoleh hal ini menyatakan bahwa teknik Certainty Of Response Index (CRI) efektif dalam mengidentifikasi miskonsepsi siswa yang dimana masih ditemukan miskonsepsi siswa pada konsep bilangan bulat, berikut ada dua kategorinya :

1. Jenis-jenis kesalahan konsep (miskonsepsi) yang ditemukan pada penelitian ini untuk uji tes pertama, kedua, dan ketiga dengan menggunakan tehnik CRI pada materi bilangan bulat di kelas IVc yaitu salah dalam mengubah soal cerita kedalam kalimat matematika, salah tanda positif dan negatif dalam menentukan operasi hitung penjumlahan dan pengurangan dua bilangan bulat berlawanan tanda dan bertanda sama dan salah hasil akhir operasi hitung yang dilakukan.

2. Klasifikasi miskonsepsinya dilihat pada besar presentase miskonsepsinya yaitu untuk uji tes uraian pertama sebesar 31,25\% pada butir soal nomor 1 tergolong pada klasifikasi miskonsepsi berkategori sedang, untuk uji tes uraian kedua besar presentasenya 6,25\%,6,25\%, dan 9,375\% pada butir soal 1,2 , dan 3 , tergolong pada klasifikasi miskonsepsi berkategori rendah, dan untuk uji tes uraian ketiga besar presentasenya $31,25 \%$ pada butir soal 1 dan tergolong pada klasifikasi miskonsepsi berkategori sedang. 


\section{Daftar Pustaka}

Asih, N. M., 2009, "Penerapan metode Jarimatika Untuk Meningkatkan Pemahaman Konsep Penjumlahan dan Pengurangan pada Siswa Kelas 1 dan 2 SDN 6 Sesetan", Jurnal Pendidikan dan Pembelajaran,Vol.16, No.1 (2009), hal.1-8, dilihat 19 November 2017.

Dzufikar, A., \& Vitanti, C. A., 2017, "Miskonsepsi Matematika pada Guru Sekolah Dasar", Suska Journal of Mathematics Education, Vol.3, No.1 (2017), hal. 41-48, dilihat 21 Oktober 2017.

Gradini, E., 2016, "Miskonsepsi dalam Pembelajaran Matematika Sekolah Dasar di Dataran Tinggi Gayo", Jurnal ISSN, Vol. III, No.2 (2016)nhal.52-60, dilihat 18 November 2017.

Nurlita.,dkk., 2016, "Miskonsepsi Konsep Prasyarat Aljabar Mahasiswa Pendidikan Guru Madrasa Ibtidayah", Jurnal Didakti Matematika, Vol.3, No. 2 (2016), hal. 85-95, dilihat 22 November 2017.

Ompusunggu, V. D. K., 2014, "Peningkatan Kemampuan Pemahaman Matematika dan Sikap Positif terhadap Matematika Siswa SMP Nasrani 2 Medan Melalui Pendekatan Problem Posing”, Jurnal Saintech, Vol. 06, No. 04 (2014), hal. 93-105, dilihat 18 November 2017.

Rizky, U.,D.,dkk.,2017 “Analisis Pengaruh Gender Terhadap Miskonsepsi Siswa Sman Di Kota Depok Dengan Menggunakan Tes Diagnosis Two-Tier”, Jurnal Prosiding Seminar Nasional Pendidikan Fkip Untirta, dilihat 31 Mei 2018.

Safitri, M. E.,dkk., 2016, "Analisis Miskonsepsi Siswa pada Materi Pecahan dalam bentuk Aljabar ditinjau dari Gaya Kognitif Siswa kelas VIII SMP Negeri 2 Adimulyo Kab. Kabumen Tahun Ajaran 2013/2014", Jurnal Elektronik Pembelajaran Matematika, Vol. 4, No. 4 (2016), hal. 401-413, dilihat 15 November 2017.

Sari, P., 2017, "Pemahaman Konsep Matematika Siswa pada Materi Besar Sudut melalui Pendekatan PMRI", Jurnal Gantang, Vol. II, No. 1 (2017), hal. 41-50, dilihat 18 November 2017.

Tuyubi, Y., R.,2005, "Identifikasi Miskonsepsi pada Konsep-konsep Fisika Menggunakan Certainty Of Response Index (CRI)", Jurnal Mimbar Pendidikan, Vol.3/XXIV/(2005), Hal. 48, dilihat 30 November 2017. 